\title{
An Examination of Audit Fees for Initial Audit Engagements after the H3C Inspection in French Context
}

\author{
Jamel Azibi $^{1}$, Catherine Grima ${ }^{2} \&$ Hubert Tondeur ${ }^{3}$ \\ ${ }^{1}$ Faculty of Law,Management and Economic Science of Jendouba, Tunisia \\ ${ }^{2}$ Business School of Lille, France \\ ${ }^{3}$ Cnam-Intec of Paris, France and CPA \\ Correspondence: Faculty of Law,Management and Economic Science of Jendouba, Tunisia., Tunisia. Tel: \\ 216-5442-2968. E-mail: jamel.az1@gmail.com
}

Received: August 18, 2019

Accepted: November 20, $2019 \quad$ Online Published: November 22, 2019

doi:10.5539/ijef.v11n12p41

URL: https://doi.org/10.5539/ijef.v11n12p41

\begin{abstract}
This paper examines the audit fees for initial audit engagements after the $\mathrm{H} 3 \mathrm{C}$ inspection in French context through 2008 to 2015. According to the theory, we suppose that audit fees increase after the start of the H3C inspection program. To test our main hypothesis, we use the methodology of the (Desir, Casterella, \& Kokina, 2013) and (Huang, Raghunandan, \& Rama, 2009) reported on the United States context. Our empirical results demonstrate that the audit fees in French context for the initial audit engagement decreased after the start of the $\mathrm{H} 3 \mathrm{C}$ inspection program. Contrary to our prediction, the massive disciplinary sanction associated to the audit fees and the less level of the audit market concentration in France, are two determinants that explain the decrease of the audit fees in this country.
\end{abstract}

Keywords: audit initials, auditor independence, H3C, audit fees

\section{Introduction}

The H3C created by the LSF Act of 2003 (LSF) to regulate the auditing profession in France after the scandal series of 2001-2002. It is considered as an independent control authority. The first goals of this new institution are to enhance auditor independence and objectivity through specified mechanisms of control. The contribution of the $\mathrm{H} 3 \mathrm{C}$ in financial transparency and the respect of the ethics code are significant. The $\mathrm{H} 3 \mathrm{C}$ developed the guidelines and a set of principles in order to reinforce the business ethics. The auditor independence is considered as the first preoccupation of this new authority. The $\mathrm{H} 3 \mathrm{C}$ drew attention to the audit fees and considers this as an important issue. For this reason, the $\mathrm{H} 3 \mathrm{C}$ imposed restriction against auditors and engaged disciplinary activity. The disciplinary activities are disclosed in the $\mathrm{H} 3 \mathrm{C}$ annual report. Starting from 2016, the emphasis of the inspection process arises because the collaboration of the $\mathrm{H} 3 \mathrm{C}$ with the PCAOB and other foreign equivalent authority. It is considered an important factor in achieving auditor independence and the respect of the ethics code. For this reason, we believe that rigors of the H3C inspection process present the opportunity for auditor independence to improve.

With the passage to the $\mathrm{H} 3 \mathrm{C}$ inspection program starting in 2007, one might expect audit fees to become more interesting for a number of reasons. First, the creation of the $\mathrm{H} 3 \mathrm{C}$ created an upward pressure on audit fees as a result of increased scrutiny, risk, and audit effort required by the mandate. Second, the auditor incurs a risk related to the $\mathrm{H} 3 \mathrm{C}$ inspection. The president in discussing the Board's inspection process, stated, “... compliance requirements ethics and the preservation of independence of the auditors are the missions of the High Council ..., almost 900 office was examined. The professional invest an important effort to improve their procedures, but we reveal a lack due to the diligence that can lead to the expression of an insufficient opinion" (Christine Guéguen, Annual Report of the H3C, 2016). Given the substantial resources devoted to Council inspection process - the income of the $\mathrm{H} 3 \mathrm{C}$ is equal to 8969 million Euro. This demonstrates the importance of the inspection program of the $\mathrm{H} 3 \mathrm{C}$.

The aim of this paper is to examine the audit fees for initial audit engagement after the starting of the $\mathrm{H} 3 \mathrm{C}$ inspection program. This is a relevant question, because audit fees are a main dimension of the European debate on the audit profession. We examine whether audit fees are increased in each year following the $\mathrm{H} 3 \mathrm{C}$ starting of 
inspection program in the case of the initial audit engagement. We expect an increase in audit fees after the starting of the process of the inspection of the $\mathrm{H} 3 \mathrm{C}$ for the initial audit engagement. To test this hypothesis, we use the methodology of (Desir et al., 2013) and (Huang et al., 2009) through 2008 to 2015 in French context which characterized by the presence of the joint audit system. Empirical results demonstrate that audit fees for initial audit decrease from 2008 to 2015 in French context. The inspection and the disciplinary activity reported on the audit fees by the H3C explain the decrease level of the audit fees (Desir et al., 2013).

The remainder of the paper is organized as follows. Section 'institutional aspect' treats the legal form of the H3C. Section 'literature review' provides further background and presents our hypothesis. Our research method appears in section 'methodology', and section 'results' present our results. Section 'other analyses' contains other analyses and section 'summary, implications, and limitations' present a summary and the implications and limitations of our findings.

\section{H3C: The Institutional Aspect}

In France, the H3C was created by the LSF Act of 2003 (LSF) to regulate the auditing profession. It is considered as an equivalent of the PCAOB in the United States. The first goals of this new authority are to guarantee auditor independence and objectivity through the mechanism of control. The contribution of the H3C in the respect of the ethics code is very significant. The disclosure of the $\mathrm{H} 3 \mathrm{C}$ annual report informs on the control approach and explains the details of the disciplinary activity of this new regulation authority.

According to the LSF of 2003, the composition of the H3C is as follows:

- Three judges from the court of cassation

- The court of auditors and the judiciary and the president being a judge of the court of cassation;

- The chairperson of the financial market authority;

- $\quad$ Representative of the ministry of economy;

- University professor specializing in legal, economic or financial studies.

- Three qualified persons in the economic and financial domain: two of them have the expertise in an initial public offering and one has the expertise in the small and medium-sized business or association field.

- Three CPA, two of them have experience in the auditing of the mandate using public offering or public domain.

The $\mathrm{H} 3 \mathrm{C}$ is divided into 6 different directions. They are as follows:

- Technical direction: assure the coordination on the specific topic

- $\quad$ Norms and ethics direction: investigation and consultation on the relativity practice and doctrine;

- $\quad$ Services of international cooperation: established the partnership with the foreign supervisory authority;

- Law direction: responsible for the law auditor control and the role of the authority;

- Direction of the supervision and control: Guides the control activity. They supervise the control realized by the professional instance and elaborate the recommendation of the control.

- Control direction: control the auditors in the public corporation.

The $\mathrm{H} 3 \mathrm{C}$ continued their development control activity with the National Consultation Group to approve the accounting standards for the adoption of the International Standards of auditing (ISA). Recently, the H3C collaborated with the European Authority in concordance with the guidelines of the European Directive of 2006/43/CE and it was concluded a collaboration project with the PCAOB and other equivalent authority.

\section{Literature Review}

Prior studies were studied in the US context. The Sarbanes-Oxley Act of 2002 and the Public Company Oversight Board imposed new restrictions on audit firm activity that auditors can provide to their client. This is due to the series scandal of 2001 and 2002. To increased auditor independence, the PCAOB increased its enforcement activities related to the audit fees after 2002. The regulatory actions and the announcement of the start of the inspection process highlighted the importance of auditor independence and the consciousness around the business ethics during this period. Several research treat the impact this new enforcement rules on audit fees in the post-Sox period. (Desir et al., 2013) re-examined the audit fees for the initial audit engagements in the Post-Sox period. They investigate whether lowballing exists in new auditor-client relationships in an "extended" post-SOX environment for the years 2007 to 2010. Their results suggest that both Big 4 and non-Big 4 
accounting firms discounted their initial-year audit fees during our sample period (2007-2010). (Sankaraguruswamy, Whisenant, \& Willenborg, 2012) analyze initial-year audit fees discounting and subsequent audit fee increases for companies that switched from one Big auditor to another Big between 2000 to 2007. They find significant initial-year fees discounting for each year between 2001 and 2006 and significant fee increases in the second year of a Big engagement. (Huang et al., 2009) studied the audit fees for initial audit engagements before after Sox. They find that in 2005-2006 Big 4 clients pay an initial-year audit fee premium of around 16 percent. We also document that the Big 4 are much less likely to serve as a successor, following an auditor change, in 2005-2006 than in 2001. The results also suggest that the Big 4 have become more conservative in the post-SOX period with respect to client acceptance and pricing decisions. In the same perspective (Charles, Glover, \& Sharp, 2010) studied the association between financial reporting risk and audit fees before and after the Sarabanes-Oxley Act. (Wang \& Zhou, 2012) investigate the impact of the Public Company Accounting Oversight Board (PCAOB) Auditing Standard No. 5 (AS5) on audit fees and audit quality. They use a large sample of accelerated filers subject to AS5 they find evidence that audit fees decrease upon the adoption of AS5 and improve the efficiency of internal control audits. (Houston \& Stefaniak, 2013) investigate and compare partner perceptions of Public Company Accounting Oversight Board (PCAOB) inspections and internal quality reviews for 107 audit partners from large public accounting firms. They find that a majority of partners can or try to predict the year of both reviews and perceive that, relative to PCAOB inspections, reviewers have a better understanding of firms' audit methodologies. (Stefaniak, Houston, \& Brandon, 2017) investigate the perception risk of internal quality reviews and analyze the PCAOB inspection. The empirical results demonstrate that those different element influence the audit effort and as consequence an audit fees. In the same perspective (Daugherty, Dickins, \& Tervo, 2011) surveyed leaders of firms subject to triennial PCAOB inspections. In general, the respondents reported that they increase audit hours and audit fees when they anticipate inspections. (Church \& Shefchik, 2011) studied the PCAOB's inspection reports of large, annually inspected accounting firms. They find that the inspection reports identify audit deficiencies that have implications for audit quality. To resolve this problem an important effort and a high level of audit hours must be anticipated and typically, the audit fees will be increased.

(Glover, Taylor, \& Wu, 2014) introduced the concept of inspection risk because the rigor of the inspection process (Riley Jr, Jenkins, Roush, \& Thibodeau, 2008). This risk behavior of audit firms increased when the auditor is the first year initial and when the PCAOB announce the penalty against auditors. The expected improvements to audit fees are the direct effect of PCAOB creation and their inspection effectiveness on the audit firm behavior. Therefore, the audit firms added a risk premium into audit fees after the creation of the PCAOB. For example, when auditor is initial audit years is faced with high engagement risk, he typically increase planned audit hours, evidence requirements (Simunic, 1980), (Pratt \& Stice, 1994); (Houston, Peters, \& Pratt, 1999) and, of course, the audit fees. The disciplinary penalties of the PCAOB and other equivalent authority through the world are one of the leading risks facing the auditor and it can significantly influence his behavior after the inspection process. In sum, the regulatory changes made by the PCAOB influence the audit fees. In attempt to mitigate audit costs, the PCAOB amended Auditing Standard No. 2 and proposed Auditing Standard No. 5.

In France, The Security of Law Act of 2003 (LSF) created the H3C to oversee public company audits in France by establishing auditing standards and registering and inspecting public company auditors. By the end of 2016, the $\mathrm{H} 3 \mathrm{C}$ had registered 2,363 audit firms in France. In addition, the board of this new authority conducts annual inspections of accounting firms that provide audit reports after the control process. These inspections evaluated the quality of audit work performed on selected audit engagements, the accounting firms' quality control system and the respect of the ethics code. The establishment of the $\mathrm{H} 3 \mathrm{C}$ and the starting of the inspection process, in particular, produces strong incentives for auditors to increase their audit fees for more than one reason. For example, the audit risks are related to the audit engagement. The $\mathrm{H} 3 \mathrm{C}$ inspection focuses on the discovery of the audit deficiencies and the identification of the material errors undetected by the auditor in his legal audit mission. The discovery of this misstatement exposed the auditor to the blame or other types of $\mathrm{H} 3 \mathrm{C}$ penalty. At this moment, the auditor is less willing to accept errors in financial statements and he should increase his planned audit hours and his requirement evidence because he risks initials of their reputation that can result from the $\mathrm{H} 3 \mathrm{C}$ penalty and subsequently the Initial of the audit market share. Therefore, the audit fees should be greater when the audit is initial audit years and when the engagement risk is very significant. This risk engagement can significantly influence the auditor behavior (Lowe, Reckers, \& Whitecotton, 2002). Prior audit studies demonstrate that engagement risk influences auditors' decision-making behavior (Knapp, 1985) (Walo, 1995) (Hackenbrack \& Nelson, 1996) (Johnstone, 2000) and is a dimension of the overall audit environment (Bell, Bedard, Johnstone, \& Smith, 2002). For example, when auditors are confronted with high engagement risk, they 
typically increase audit fees, audit hours, and further evidence requirements (Simunic, 1980) (Houston, et al., 1999; Pratt \& Stice, 1994). Thus, we predict that audit fees will increase significantly after the initial audit year and the after the enhancement of the $\mathrm{H} 3 \mathrm{C}$ inspection process on audit firms (Annual Report of the H3C, 2011, 2012 and 2013).

\section{Methodology}

Our sample selection process follows the following steps. First, we begin with all companies that have at least two years of audit fee data on Thomson Financial databases from 2008 to 2015. Second, we eliminate observations with calendar year end; SIC codes equal to or greater than 6000 foreigners businesses, banks, insurance companies. Following (Huang et al., 2009) and other prior fee studies (e.g., Simunic, 1980; Casterella, Francis, Lewis, \& Walker, 2004), we estimate the following audit fees regression model which includes natural logarithm as an experimental variable. This variable provides information on economic relation auditor-clients. The fees depend on the auditor reputation and the risk factor. The announcement of the establishment of the $\mathrm{H} 3 \mathrm{C}$ and the start of the inspection program may cause a change in the auditor's assessment of expected initials arise from potential penalties. We use a dummy variable equal to 1 if one of the auditors is initial audit year, 0 otherwise. We use others control variables to capture company size (LnTA), complexity (EMPLOY), risk (RECINV, LIQ), and profitability (ROA) because first prior research interest in this relationship. We estimate the following model for each year 2008-2015.

Table 1. Sample characteristics

\begin{tabular}{lcccccccccc}
\hline Sector & ICB industry code & 15 & 14 & 13 & 12 & 11 & 10 & 09 & 08 & 07 \\
\hline Basic Materials & 1000 & 15 & 18 & 17 & 17 & 15 & 14 & 12 & 14 & 11 \\
Consumer Goods & 3000 & 50 & 61 & 69 & 63 & 66 & 59 & 48 & 51 & 44 \\
Consumer Services & 5000 & 44 & 63 & 62 & 60 & 56 & 51 & 44 & 49 & 46 \\
Health Care & 4000 & 32 & 38 & 36 & 32 & 29 & 23 & 18 & 18 & 18 \\
Industrials & 2000 & 66 & 64 & 68 & 68 & 63 & 59 & 54 & 53 & 44 \\
Oil and Gas & 0001 & 7 & 9 & 7 & 6 & 5 & 5 & 4 & 6 & 5 \\
Technology & 9000 & 49 & 65 & 72 & 67 & 62 & 54 & 50 & 49 & 44 \\
Telecommunications & 6000 & 3 & 2 & 4 & 4 & 4 & 3 & 3 & 3 & 3 \\
Utilities & 7000 & 11 & 11 & 12 & 7 & 9 & 9 & 10 & 5 & 6 \\
Total & & 277 & 331 & 347 & 324 & 309 & 275 & 243 & 247 & 221 \\
\hline
\end{tabular}

To examine changes in fees in response to the establishment of the $\mathrm{H} 3 \mathrm{C}$ and the start of the inspection program, it is important to control changes in underlying client characteristics. We estimate the following pooled audit fees regression model for every year starting from using ordinary least squares regression:

$$
L n F E E=\beta_{0}+\beta_{1} L n T A+\beta_{2} R E C I N V+\beta_{3} E M P L O Y+\beta_{4} L I Q+\beta_{5} L E V+\beta_{6} R O A+\beta_{7} I N I T I A L+\beta_{8} A U D I T O R+\zeta
$$

$\mathrm{LnFEE}=$ natural logarithm of audit fees;

LnTA = natural logarithm of total assets;

RECINV =percentage of total assets in receivables and inventories;

EMPLOY= natural logarithm of total employers;

LIQ = current ratio;

Lev $=$ debt-to-assets ratio;

$\mathrm{ROA}=$ return on assets;

INITIAL $=1$ if one of the two auditor is initial year audit, else 0 ;

AUDITOR $=1$ if the two Auditor are Big, 0 otherwise.

In addition to the "levels" regression above, we estimate the audit fee "changes" regression model listed below. Each variable in this model is calculated as the difference between its value in the current year and its value in the previous year. Due to the collinearity problem, we delete the auditor variable. The model of audit fees differences is as follows:

$$
D L n F E E=\alpha_{0}+\alpha_{1} D L n T A+\alpha_{2} D R E C I N V+\alpha_{3} D E M P L O Y+\alpha_{4} D L I Q+\alpha_{5} D L E V+\alpha_{6} D R O A+{ }_{\alpha 7} \text { DINITIAL }+\zeta
$$




\section{Results}

Table 2. Descriptive statistics

\begin{tabular}{|c|c|c|c|c|c|c|}
\hline & ear 200 & & & & & \\
\hline VARIABLES & $\mathrm{N}$ & mean & SD & $\min$ & Median & $\max$ \\
\hline LnFEE & 221 & 13.59 & 1.939 & 9.210 & 13.236 & 20.91 \\
\hline LnTA & 221 & 6.334 & 2.367 & 0.732 & 6.111 & 12.13 \\
\hline RECINV & 221 & 4.463 & 6.573 & 1.143 & 2.591 & 69.50 \\
\hline EMPLOY & 221 & 7.699 & 2.532 & 1.609 & 7.768 & 12.96 \\
\hline LIQ & 221 & 1.634 & 1.117 & 0.240 & 1.37 & 10.20 \\
\hline LEV & 221 & 0.228 & 0.197 & 0 & 0.205 & 2.064 \\
\hline \multirow[t]{2}{*}{ ROA } & 221 & 5.800 & 9.618 & -42.29 & 5.71 & 49.25 \\
\hline & ear 200 & & & & & \\
\hline VARIABLES & $\mathrm{N}$ & mean & SD & $\min$ & Median & $\max$ \\
\hline LnFEE & 247 & 13.44 & 1.828 & 9.210 & 13.142 & 19.84 \\
\hline LnTA & 247 & 6.239 & 2.353 & 0.728 & 5.883 & 12.02 \\
\hline RECINV & 247 & 7.847 & 53.53 & 1.010 & 2.509 & 835.2 \\
\hline EMPLOY & 247 & 7.599 & 2.513 & 1.609 & 7.520 & 12.96 \\
\hline LIQ & 247 & 1.925 & 5.817 & 0.150 & 1.320 & 90.19 \\
\hline LEV & 247 & 0.261 & 0.232 & 0 & 0.229 & 2.334 \\
\hline \multirow[t]{2}{*}{ ROA } & 247 & 3.245 & 11.81 & -63.56 & 4.47 & 81.74 \\
\hline & $\operatorname{ear} 200$ & & & & & \\
\hline VARIABLES & $\mathrm{N}$ & mean & SD & $\min$ & Median & $\max$ \\
\hline LnFEE & 243 & 13.38 & 1.754 & 9.210 & 13.060 & 19.79 \\
\hline LnTA & 243 & 6.038 & 2.318 & 1.850 & 5.691 & 12.04 \\
\hline RECINV & 243 & 6.951 & 37.88 & 1.142 & 2.696 & 586 \\
\hline EMPLOY & 243 & 7.467 & 2.517 & 1.609 & 7.324 & 12.96 \\
\hline LIQ & 243 & 1.771 & 1.884 & 0.240 & 1.400 & 21.58 \\
\hline LEV & 243 & 0.248 & 0.309 & 0 & 0.204 & 3.485 \\
\hline \multirow[t]{2}{*}{ ROA } & 243 & 1.001 & 11.10 & -85.67 & 2.8 & 37.91 \\
\hline & ear 201 & & & & & \\
\hline VARIABLES & $\mathrm{N}$ & mean & $\mathrm{SD}$ & $\min$ & Median & $\max$ \\
\hline LnFEE & 275 & 13.33 & 1.871 & 9.210 & 13.060 & 21.52 \\
\hline LnTA & 275 & 6.026 & 2.365 & 0.728 & 5.676 & 12.12 \\
\hline RECINV & 275 & 8.168 & 56.41 & 1.005 & 2.734 & 933.5 \\
\hline EMPLOY & 275 & 7.473 & 2.499 & 1.609 & 7.341 & 12.86 \\
\hline LIQ & 275 & 2.190 & 7.631 & 0.0600 & 1.360 & 125.2 \\
\hline LEV & 275 & 0.231 & 0.282 & 0 & 0.191 & 3.379 \\
\hline \multirow[t]{2}{*}{ ROA } & 275 & 2.580 & 11.97 & -84.96 & 4.08 & 64.81 \\
\hline & ear 201 & & & & & \\
\hline VARIABLES & $\mathrm{N}$ & mean & SD & $\min$ & Median & $\max$ \\
\hline LnFEE & 309 & 13.26 & 1.885 & 9.210 & 13.060 & 21.39 \\
\hline LnTA & 309 & 6.011 & 2.423 & -2.813 & 5.734 & 12.26 \\
\hline RECINV & 309 & 4.860 & 7.784 & 1.102 & 2.697 & 77.85 \\
\hline EMPLOY & 309 & 7.395 & 2.536 & 1.609 & 7.289 & 12.96 \\
\hline LIQ & 309 & 1.643 & 1.632 & 0.0500 & 1.310 & 22.21 \\
\hline LEV & 309 & 3.747 & 61.82 & 0 & 0.202 & 1,087 \\
\hline \multirow[t]{2}{*}{ ROA } & 309 & 2.267 & 17.05 & -201.2 & 3.87 & 80.55 \\
\hline & ear 201 & & & & & \\
\hline VARIABLE & $\mathrm{N}$ & mean & SD & $\min$ & Median & $\max$ \\
\hline LnFEE & 324 & 13.02 & 1.840 & 9.210 & 12.794 & 19.44 \\
\hline LnTA & 324 & 5.752 & 2.423 & 0.652 & 5.334 & 12.23 \\
\hline RECINV & 324 & 10.96 & 116.7 & 1.202 & 2.733 & 2,102 \\
\hline EMPLOY & 324 & 7.155 & 2.623 & 1.099 & 6.896 & 12.96 \\
\hline LIQ & 324 & 1.712 & 1.508 & 0.280 & 1.360 & 16.27 \\
\hline LEV & 324 & 0.215 & 0.213 & 0 & 0.187 & 2.186 \\
\hline ROA & 324 & 0.190 & 17.63 & -133.8 & 3.185 & 92.27 \\
\hline
\end{tabular}




\begin{tabular}{|c|c|c|c|c|c|c|}
\hline & ear 20 & & & & & \\
\hline VARIABLES & $\mathrm{N}$ & mean & SD & $\min$ & Median & $\max$ \\
\hline LnFEE & 347 & 13.00 & 1.842 & 9.210 & 12.676 & 20.58 \\
\hline LnTA & 347 & 5.670 & 2.549 & -4.605 & 5.263 & 12.44 \\
\hline RECINV & 347 & 5.597 & 16.02 & 1.199 & 2.867 & 231.7 \\
\hline EMPLOY & 347 & 7.048 & 2.579 & 1.099 & 6.895 & 12.96 \\
\hline LIQ & 347 & 1.713 & 2.367 & 0 & 1.360 & 41.65 \\
\hline LEV & 347 & 19.88 & 365.6 & 0 & 0.202 & 6,811 \\
\hline \multirow[t]{2}{*}{ ROA } & 347 & -3.427 & 28.80 & -310 & 3.15 & 22.98 \\
\hline & \multicolumn{6}{|c|}{ year 2014} \\
\hline VARIABLES & $\mathrm{N}$ & mean & SD & $\min$ & Median & $\max$ \\
\hline LnFEE & 331 & 13.04 & 1.802 & 9.210 & 12.676 & 20.48 \\
\hline LnTA & 331 & 5.775 & 2.354 & 0.784 & 5.293 & 12.14 \\
\hline RECINV & 330 & 5.874 & 15.61 & 1.186 & 3.036 & 219 \\
\hline EMPLOY & 331 & 7.118 & 2.564 & 1.609 & 6.891 & 12.96 \\
\hline LIQ & 331 & 2.154 & 5.097 & 0.370 & 1.480 & 84.37 \\
\hline LEV & 331 & 0.225 & 0.266 & 0 & 0.194 & 3.813 \\
\hline ROA & 331 & -0.261 & 18.04 & -172.1 & 3.12 & 56.38 \\
\hline \multicolumn{7}{|c|}{ year 2015} \\
\hline VARIABLES & $\mathrm{N}$ & mean & SD & $\min$ & Median & $\max$ \\
\hline LnFEE & 277 & 13.23 & 1.743 & 9.210 & 12.995 & 20.62 \\
\hline LnTA & 277 & 6.131 & 2.271 & 1.051 & 5.856 & 11.98 \\
\hline RECINV & 277 & 5.217 & 10.22 & 1.231 & 2.920 & 149.1 \\
\hline EMPLOY & 277 & 7.359 & 2.502 & 1.609 & 7.311 & 12.96 \\
\hline LIQ & 277 & 2.359 & 7.527 & 0.290 & 1.5 & 110.7 \\
\hline LEV & 277 & 0.225 & 0.186 & 0 & 0.2 & 1.659 \\
\hline ROA & 277 & -0.0364 & 16.44 & -146.9 & 3.45 & 54.11 \\
\hline
\end{tabular}

Table 2 presents descriptive data for our samples of companies for the years 2007 through 2015, and table 3 presents the changes in percentages. First, with respect to median values of audit fees, we note that clients seem to pay more in audit fees especially in 2007 and 2008, where the median value of the audit fees variable are respectively 13.236 and 13.142 . This is due to the $\mathrm{H} 3 \mathrm{C}$ inspection program for the first time in 2007. This authority was imposed restriction against auditors and engaged dispensary activity in 2007 and 2008 compared 2006 (Azibi, Tondeur, \& Azibi, 2017). This risk behavior explains this important increase of median fees (Azibi, et al., 2017). The most important changes in audit fees were in 2013. The change mean is equal to $0.843 \%$. This result signals the intensity of the $\mathrm{H} 3 \mathrm{C}$ inspection process (H3C, report 2014) and the collaboration with others equivalent authority in Europe and the PCAOB in the United States. Second, the median level of the total assets (LnTA) is variable every year. In sum is around the average of 5.5. The median value is positive every year. Third, the mean of the employ variable is around 7. The changes of this variable in the majority are positive except the 2012 and 2015. However, for leverage and the liquidity variables, there are no significant differences between years. Finally, $67.25 \%$ of the observation of our sample are associated at least one Big Four audit (Table 4). This result demonstrates that French enterprise choice at least one of the two legal auditors one of the Big Four networks with only $6 \%$ only is the initial year audit. This last percentage is lower compared to the US context because the legal mandate of the legal auditor in France (six years in France and only one year in USA). This strategy of the auditor choice in French context reduces the market concentration and is in accordance with the recommendation of European Green paper of 2010 (Velte \& Azibi, 2015).

Table 3. Changes in percentage

\begin{tabular}{cccccccccccccccccccc}
\hline & \multicolumn{4}{c}{2008} & \multicolumn{2}{c}{2009} & \multicolumn{2}{c}{2010} & \multicolumn{2}{c}{2011} & \multicolumn{2}{c}{2012} & \multicolumn{2}{c}{2013} & \multicolumn{2}{c}{2014} & 2015 \\
\cline { 2 - 5 } & Mean & Median & Mean & Median & Mean & Median & Mean & Median & Mean & Median & Mean & Median & Mean & Median & Mean & Median \\
\hline DLnFEE & -0.030 & 0.163 & 0.331 & 0.000 & -0.078 & 0.000 & -0.170 & 0.000 & -0.261 & 0.117 & 0.843 & 0.108 & 0.552 & 0.000 & 0.144 & 0.071 \\
DLnTA & 0.865 & 0.424 & -0.709 & -0.207 & 0.891 & 0.754 & 0.581 & 0.732 & 1.048 & 0.321 & 0.864 & 0.218 & 3.543 & 0.778 & 2.085 & 0.764 \\
DEMPLOY & 0.124 & 0.000 & 0.051 & 0.000 & 0.300 & 0.000 & 0.077 & 0.000 & -0.032 & 0.000 & 0.088 & 0.000 & 0.219 & 0.000 & -0.234 & 0.000 \\
DLIQ & 9.148 & -1.144 & 5.788 & 1.707 & 2.953 & 0.000 & 1.243 & -1.747 & 4.251 & 0.806 & 3.891 & -0.989 & 16.752 & 1.749 & 5.538 & 0.000 \\
DLEV & 30.578 & 5.256 & 20.632 & -1.802 & 11.889 & -6.952 & 196.709 & -1.291 & 25.591 & -3.523 & 78.080 & 1.226 & 12.412 & -0.759 & 120.962 & 0.818 \\
\hline
\end{tabular}


Table 4. Frequency for dummy variables

\begin{tabular}{ccccccc}
\hline Variables & \multicolumn{3}{c}{ Auditor } & \multicolumn{3}{c}{ Initial } \\
\cline { 2 - 7 } & Freq. & Percent & Cum. & Freq. & Percent & Cum. \\
\hline 0 & 843 & 32.75 & 32.75 & 2,42 & 94.01 & 94.01 \\
1 & 1,731 & 67.25 & 100.00 & 154 & 5.99 & 100.00 \\
Total & 2,574 & 100.00 & & 2,574 & 100.00 & \\
\hline
\end{tabular}

Table 5. Audit fees regression

\begin{tabular}{|c|c|c|c|c|c|c|c|c|}
\hline VARIABLES & $\begin{array}{l}(2008) \\
\operatorname{lnfee}\end{array}$ & $\begin{array}{l}\text { (2009) } \\
\text { lnfee }\end{array}$ & (2010) & (2011) & (2012) & (2013) & (2014) & (2015) \\
\hline \multirow[t]{2}{*}{$\operatorname{lnta}$} & $0.672 * * *$ & $0.653 * * *$ & $0.669 * * *$ & $0.635 * * *$ & $0.670 * * *$ & $0.631 * * *$ & $0.649 * * *$ & $0.655^{* * * *}$ \\
\hline & $(0.0328)$ & $(0.0349)$ & $(0.0387)$ & $(0.0358)$ & $(0.0304)$ & $(0.0310)$ & $(0.0292)$ & $(0.0367)$ \\
\hline \multirow[t]{2}{*}{ recinv } & $-0.00205^{* *}$ & 0.00137 & -0.00205 & -0.0145 & 0.000193 & -0.00226 & $-0.00825 * *$ & -0.0117 \\
\hline & (0.000979) & $(0.00175)$ & $(0.00144)$ & $(0.00924)$ & $(0.000474)$ & $(0.00401)$ & $(0.00389)$ & $(0.00752)$ \\
\hline \multirow[t]{2}{*}{ employ } & 0.0414 & 0.0469 & 0.0101 & 0.0428 & 0.0124 & $0.0649 * *$ & 0.0404 & 0.0327 \\
\hline & $(0.0300)$ & $(0.0312)$ & $(0.0348)$ & $(0.0336)$ & $(0.0271)$ & $(0.0286)$ & $(0.0265)$ & $(0.0318)$ \\
\hline \multirow[t]{2}{*}{ liq } & -0.0127 & $-0.0809 * * *$ & -0.00744 & -0.0348 & -0.0487 & -0.0193 & 0.00403 & 0.00604 \\
\hline & $(0.00982)$ & $(0.0266)$ & $(0.00788)$ & $(0.0440)$ & $(0.0393)$ & $(0.0273)$ & (0.0107) & $(0.0103)$ \\
\hline \multirow[t]{2}{*}{ lev } & -0.0836 & -0.0962 & 0.0171 & 0.00169 & -0.137 & $0.170^{*}$ & 0.630 *** & $0.510^{*}$ \\
\hline & $(0.230)$ & $(0.220)$ & $(0.292)$ & $(0.00138)$ & $(0.233)$ & $(0.0923)$ & $(0.167)$ & $(0.267)$ \\
\hline \multirow[t]{2}{*}{ roa } & 0.00472 & $-0.0206^{* * *}$ & 0.00928 & -0.00187 & 0.00110 & $-0.00435^{*}$ & $-0.00767 * *$ & $-0.00765^{* *}$ \\
\hline & (0.00594) & $(0.00547)$ & $(0.00612)$ & $(0.00559)$ & $(0.00329)$ & $(0.00253)$ & $(0.00358)$ & $(0.00384)$ \\
\hline \multirow[t]{2}{*}{ Initial } & $-0.387 * *$ & -0.155 & $-0.624 * * *$ & $-0.371 * *$ & $-0.356^{* * *}$ & $-0.216^{*}$ & 0.0516 & 0.0206 \\
\hline & $(0.154)$ & (0.133) & $(0.178)$ & $(0.175)$ & $(0.129)$ & $(0.115)$ & $(0.125)$ & $(0.136)$ \\
\hline \multirow[t]{2}{*}{ auditor } & 0.101 & 0.0468 & 0.165 & 0.193 & 0.164 & 0.109 & 0.125 & 0.137 \\
\hline & $(0.111)$ & (0.109) & $(0.133)$ & $(0.128)$ & $(0.102)$ & (0.0973) & $(0.0955)$ & $(0.111)$ \\
\hline \multirow[t]{2}{*}{ Constant } & $9.206^{* * *}$ & $9.338 * * *$ & $9.599 * * *$ & $9.409 * * *$ & $9.352 * * *$ & $9.015^{* * * *}$ & $8.781 * * *$ & $8.800 * * *$ \\
\hline & $(0.196)$ & $(0.192)$ & $(0.231)$ & $(0.236)$ & (0.199) & $(0.162)$ & $(0.166)$ & $(0.182)$ \\
\hline Observations & 247 & 243 & 275 & 309 & 320 & 345 & 330 & 275 \\
\hline R-squared & 0.836 & 0.835 & 0.739 & 0.724 & 0.808 & 0.814 & 0.820 & 0.799 \\
\hline Prob $>F$ & 0.0000 & 0.0000 & 0.0000 & 0.0000 & 0.0000 & 0.0000 & 0.0000 & 0.0000 \\
\hline
\end{tabular}

Standard errors in parentheses: $* * * \mathrm{p}<0.01, * * \mathrm{p}<0.05,{ }^{*} \mathrm{p}<0.1$.

Table 6. Differences of audit fees regression

\begin{tabular}{lcccccccc}
\hline VARIABLES & 2008 & 2009 & 2010 & 2011 & 2012 & 2013 & 2014 & 2015 \\
Intadiff & $0.579 *$ & 0.256 & $0.497 * * *$ & 0.190 & 0.00604 & $0.552^{* *}$ & $0.388^{* * *}$ & $0.493^{* * *}$ \\
& $(0.326)$ & $(0.163)$ & $(0.120)$ & $(0.192)$ & $(0.248)$ & $(0.247)$ & $(0.149)$ & $(0.149)$ \\
recindiff & -0.00838 & $-0.00398^{*}$ & $-0.00456^{* * *}$ & 0.00398 & $0.000240 * * *$ & -0.00510 & -0.00106 & -0.0256 \\
& $(0.0131)$ & $(0.00229)$ & $(0.000278)$ & $(0.00653)$ & $(7.49 \mathrm{e}-05)$ & $(0.00451)$ & $(0.00111)$ & $(0.0157)$ \\
employdiff & -0.474 & 0.0414 & $0.600^{*}$ & -0.0830 & -0.182 & -0.0556 & 0.0425 & 0.0521 \\
& $(0.324)$ & $(0.146)$ & $(0.327)$ & $(0.203)$ & $(0.336)$ & $(0.0899)$ & $(0.0570)$ & $(0.0531)$ \\
liqdiff & 0.00108 & 0.00319 & -0.00441 & 0.000204 & -0.0658 & 0.0553 & -0.000309 & -0.0105 \\
& $(0.00617)$ & $(0.0146)$ & $(0.00455)$ & $(0.000671)$ & $(0.0492)$ & $(0.0413)$ & $(0.00275)$ & $(0.00860)$ \\
levragediff & $1.074 * *$ & 0.0667 & $0.619 * *$ & 0.00490 & -0.435 & 0.0506 & 0.0797 & 0.173 \\
& $(0.469)$ & $(0.242)$ & $(0.299)$ & $(0.00549)$ & $(0.631)$ & $(0.105)$ & $(0.169)$ & $(0.149)$ \\
roadiff & 0.000907 & -0.00352 & -0.00198 & 0.00229 & -0.00251 & -0.00128 & 0.00249 & -0.00501 \\
& $(0.00285)$ & $(0.00334)$ & $(0.00167)$ & $(0.00318)$ & $(0.00307)$ & $(0.00459)$ & $(0.00581)$ & $(0.00404)$ \\
initialdiff & $-0.115 * *$ & 0.0303 & 0.0585 & -0.0346 & -0.128 & -0.0360 & -0.0887 & 0.174 \\
& $(0.0544)$ & $(0.0492)$ & $(0.0415)$ & $(0.0497)$ & $(0.190)$ & $(0.0974)$ & $(0.0710)$ & $(0.131)$ \\
Constant & -0.0739 & $0.0375^{*}$ & -0.0354 & $-0.0383 *$ & -0.0857 & 0.0622 & 0.0180 & -0.0315 \\
& $(0.0650)$ & $(0.0214)$ & $(0.0223)$ & $(0.0219)$ & $(0.0619)$ & $(0.0515)$ & $(0.0205)$ & $(0.0352)$ \\
Observations & 204 & 218 & 255 & 284 & 268 & 299 & 315 & 269 \\
R-squared & 0.040 & 0.036 & 0.193 & 0.009 & 0.009 & 0.021 & 0.137 & 0.045 \\
Prob > F & 0.0000 & 0.0000 & 0.0000 & 0.0000 & 0.0000 & 0.0000 & 0.0000 & 0.0000 \\
\hline
\end{tabular}

Robust standard errors in parentheses: $* * * \mathrm{p}<0.01,{ }^{*} \mathrm{p}<0.05,{ }^{*} \mathrm{p}<0.1$. 
Table 5 and 6 present respectively the results of the audit fees regressions from 2008 to 2010. Our primary focus is on the sign and the statistical significance of the INITIAL variable. Contrary to our prediction in the audit fees model, this variable is negative significant at $1 \%$ in 2008, 2010, 2011, 2012, and at 5\% in 2013. This demonstrates that audit firms in the case of the initial audit firm reduce their fees. The improvement of the inspection process on audit fees was increased in 2011, 2012 and 2013 compared to 2008, 2009 and 2010 (H3C annual report). The $\mathrm{H} 3 \mathrm{C}$ announced in their different annual report an important number of disciplinary activities associated to the audit fees. The competitive on the audit market between auditors in France is an additional factor that influences the audit fees. If we refer to the audit difference model, we find that this decrease between audit fees and initial audit is only significant negative in 2008 and non-significant in 2011 and 2012. This result demonstrates that this decrease is not significant. In addition, the control variables in all the regressions have the expected sign. Audit fees increase with client size (LnTA is positive and significant in all regressions). The complexity variable (Employ) is positive and significant only in 2013. This signals that the audit is considered only as a legal mechanism, contrary to the hypothesis of the deep pocket theory. This conclusion is supported by the sign of the RECINV variable.

\section{Conclusion}

The audit fees are considered as an important dimension of the audit reforms after the scandal series of 2001 to 2002. The establishment of an independent authority to ensure the respect of the recent reforms of the audit profession is the main characteristics of last decades. The role of the $\mathrm{H} 3 \mathrm{C}$ in France is fundamental in the French environment. The inspection process of this authority was started in 2007. The aim of this research is to examine whether audit fees are increased in each year following the $\mathrm{H} 3 \mathrm{C}$ starting of inspection program for all audited companies in France from 2008 to 2015 in a French context which characterized by the joint audit. Contrary to our prediction, the empirical results demonstrate that the audit firms in the case of the initial audit reduce their fees. The announcement and the disclosure of the disciplinary sanction have an important impact on audit fees. The audit market concentration and the role of the joint audit is other factors that influence the auditor choice and the audit fees.

\section{References}

Annual Report of the H3C, 2008. 2009, 2010, 2011, 2012, 2013, 2014, 2015, 2016.

Azibi, J., Hubert, T., \& Hamza, A. (2017). The Impact of the H3C on Auditor Independence in French Context. Journal of Management and Sustainability, 7, 105. https://doi.org/10.5539/jms.v7n2p105

Bell, T. B., Jean, C. B., Karla, M. J., \& Edward, F. S. (2002). KRiskSM: A computerized decision aid for client acceptance and continuance risk assessments. Auditing: A Journal of Practice \& Theory, 21, 97-113. https://doi.org/10.2308/aud.2002.21.2.97

Casterella, J. R., Jere, R. F., Barry, L. L., \& Paul, L. W. (2004). Auditor industry specialization, client bargaining power, and audit pricing. Auditing: A Journal of Practice \& Theory, 23, 123-140. https://doi.org/10.2308/aud.2004.23.1.123

Charles, S. L., Steven, M. G., \& Nathan, Y. S. (2010). The association between financial reporting risk and audit fees before and after the historic events surrounding SOX. Auditing: A Journal of Practice \& Theory, 29, 15-39. https://doi.org/10.2308/aud.2010.29.1.15

Church, B. K., \& Lori, B. S. (2011). PCAOB inspections and large accounting firms. Accounting Horizons, 26, 43-63. https://doi.org/10.2308/acch-50077

Daugherty, B., Denise, D., \& Wayne, A. T. (2011). Negative PCAOB inspections of triennially inspected auditors and involuntary and voluntary client losses. International Journal of Auditing, 15, 231-246. https://doi.org/10.1111/j.1099-1123.2011.00432.x

Desir, R., Jeffrey, R. C., \& Julia, K. (2013). A reexamination of audit fees for initial audit engagements in the post-SOX period. Auditing: A Journal of Practice \& Theory, 33, 59-78. https://doi.org/10.2308/ajpt-50670

Glover, S. M., Mark, H. T., \& Wu, Y. (2014). Closing the gap between auditor performance and regulators' expectations when auditing fair value measurements: Evidence from practicing audit partners. Deloitte Foundation/University of Kansas Auditing Symposium. https://doi.org/10.2139/ssrn.2504521

Hackenbrack, K., \& Mark, W. N. (1996). Auditors' incentives and their application of financial accounting standards. Accounting Review, 43-59.

Houston, R. W., \& Chad, M. S. (2013). Audit partner perceptions of post-audit review mechanisms: An examination of internal quality reviews and PCAOB inspections. Accounting Horizons, 27, 23-49. 
https://doi.org/10.2308/acch-50323

Houston, R. W., Michael, F. P., \& Jamie, H. P. (1999). The audit risk model, business risk and audit-planning decisions. The Accounting Review, 74, 281-298. https://doi.org/10.2308/accr.1999.74.3.281

Hua-Wei, H., Kanan, R., \& Dasaratha, R. (2009). Audit fees for initial audit engagements before and after SOX. Auditing: A Journal of Practice \& Theory, 28, 171-190. https://doi.org/10.2308/aud.2009.28.1.171

Johnstone, K. M. (2000). Client-acceptance decisions: Simultaneous effects of client business risk, audit risk, auditor business risk, and risk adaptation. Auditing: A Journal of Practice \& Theory, 19, 1-25. https://doi.org/10.2308/aud.2000.19.1.1

Knapp, M. C. (1985). Audit conflict: An empirical study of the perceived ability of auditors to resist management pressure. Accounting Review, 202-211.

Lowe, D. J., Philip, M. J. R., \& Stacey, M. W. (2002). The effects of decision-aid use and reliability on jurors' evaluations of auditor liability. The Accounting Review, 77, 185-202. https://doi.org/10.2308/accr.2002.77.1.185

Pratt, J., \& James, D. S. (1994). The effects of client characteristics on auditor litigation risk judgments, required audit evidence, and recommended audit fees. Accounting Review, 639-656.

Riley, Jr, Richard, R. J., Gregory, J., Pamela, Y. R., \& Jay, C. T. (2008). Audit quality in the post-SOX audit environment: What your auditing students must know about the PCAOB inspection process. Current Issues in Auditing, 2, A17-A25. https://doi.org/10.2308/ciia.2008.2.2.A17

Sankaraguruswamy, S., Scott, W., \& Michael, W. (2012). Pricing and quality of initial audit engagements. Working paper, National University of Singapore.

Simunic, D. A. (1980). The pricing of audit services: Theory and evidence. Journal of Accounting Research, 161-190. https://doi.org/10.2307/2490397

Stefaniak, C. M., Richard, W. H., \& Duane, M. B. (2017). Investigating inspection risk: An analysis of PCAOB inspections and internal quality reviews. Auditing: A Journal of Practice \& Theory, 36, 151-168. https://doi.org/10.2308/ajpt-51518

Velte, P., \& Jamel, A. (2015). Are joint audits a proper instrument for increased audit quality. British Journal of Applied Science \& Technology, 7, 528-551. https://doi.org/10.9734/BJAST/2015/15599

Walo, J. C. (1995). The effects of client characteristics on audit scope. Auditing, 14, 115.

Wang, D., \& Jian, Z. (2012). The impact of PCAOB Auditing Standard No. 5 on audit fees and audit quality. Accounting Horizons, 26, 493-511. https://doi.org/10.2308/acch-50183

\section{Copyrights}

Copyright for this article is retained by the author(s), with first publication rights granted to the journal.

This is an open-access article distributed under the terms and conditions of the Creative Commons Attribution license (http://creativecommons.org/licenses/by/4.0/). 